\title{
NEW HOST RECORD OF ECHINOCEPHALUS OVERSTREETI DEARDORFF AND KO (1983) (NEMATODA: GNATHOSTOMATIDAE) FROM THE COMMON SEA BREAM PAGRUS PAGRUS (SPARIDAE) OF THE RED SEA IN EGYPT
}

\author{
By
}

ZEINAB I. ADAM ${ }^{1}$, SAHAR S. EL-GANAINY ${ }^{2}$, MANAL B. AHMED ${ }^{2}$, SAYED A. AHMED ${ }^{2}$, MANAL F. EL GARHY ${ }^{1 *}$ AND KAREEM S. MORSY ${ }^{1,3}$ Departments of Zoology, Faculties of Science, Cairo University ${ }^{1}$, and Minia University ${ }^{2}$, Minya, Egypt and Department of Biology, Faculty of science, King Khalid University ${ }^{3}$, Saudi Arabia ( ${ }^{*}$ Correspondence: manal_elgarhy@yahoo.com) Abstract

Several nematode species of family Gnathostomatidae are considered as fish-borne zoonotic parasites, although feral dogs and cats are the commonly identified definitive hosts of these species, humans may accidentally be part of the life cycle of these nematodes by eating undercooked fish infected by the fourth larval stages (L4). In the present study, thirty five fish specimens of the common sea bream Pagrus pagrus (Sparidae) were collected from a location along the Red Sea at Hurghada city, Cairo, Egypt. Twenty two fish were infected by the nematode parasite Echinocephalus overstreeti (family: Gnathostomatidae) isolated from the peritoneal cavity of infected fish attached externally to host viscera. After isolation and fixation, worms were examined by light and scanning electron microscopes. Morphologically, parasite possessed most of the features characterizing of Gnathostomatidae members. Body long with very narrow lateral alae, simple pseudolabia, 2 well-developed papillae and amphid, a cephalic bulb armed with six transverse rows of claw-shaped spines and a conical pointed tail equipped with anus.

Key words: Echinocephalus overstreeti, Pagrus pagrus, Gnathostomatidae, Light and scanning microscopy.

\section{Introduction}

Rapidly growing populations and the food shortage constitute the most important problems all over the world especially in Africa, so that scientists still trying to find solutions for these problems (Morsy et al, 2014). Fish play an important role in human nutrition as one of the most valuable sources of food protein also; fish farming apparently offers a solution to the problem of the increasing human population (Maghrabi et al, 2010). Animal protein is an essential element in nutrition containing nearly all essential amino acids necessary for man and animals. Worldwide, people obtain about $25 \%$ of their animal protein from fish and shell fish (Khalil et al, 2014). It is the most numerous and diverse of vertebrate groups, and has a great importance and significance in the mankind life (Al-Zubaidy, 2011).

In Egypt, the increase in human population as well as the increasing demand for fish as a source of protein has motivated their culture intensification (Morsy et al, 2013). Fisheries in the Red Sea are of considerable socio-economic importance to the Red Sea countries in terms of national food security and income generation for rural communities (De Vantier et al, 2000; González-Solís et al, 2019). Nematode parasites of the Red Sea fishes tend to be limited to short reports describing new taxa (Khalifa et al, 2015). Fish harbor a wide range of ecto- and endoparasites infecting alimentary canal, liver, kidney, reproductive organs, muscles, gills and skin (Güven and Öztürk, 2019). Nematode parasites are common in freshwater and marine fish. No doubt, fish nematodes cause veterinary and economic problems, and may be a source of zoonotic nematodes. These constitute one of the earliest helminthes in fishes in marine, brackish and fresh-water (Olsen, 1974). Adult nematodes specific to fishes are cucullanid, gnathostomatid and anisakid nematodes found in the digestive tract (Moravec and Nagasawa, 2000). 
In the present study, the nematode parasite Echinocephalus overstreeti (family: Gnathostomatidae) was isolated from the common sea bream Pagrus pagrus from Hurghada city in Egypt during a recent survey of helminthes infecting fishes of the Red Sea, they were morphologically identified on the basis of light and scanning electron microscopy.

\section{Material and methods}

Thirty five specimens of the common sea bream Pagrus pagrus (Family: Sparidae) were collected during the year 2017 from boat-landing and fishermen at Hurghada City's coasts along the Red Sea. Fish were transported to Parasitology Laboratory, Department of Zoology, Faculty of Science, and identified. After dissection, larvae were collected from the surface of stomach, intestine, and muscles; rinsed in phosphate-buffered saline (PBS); fixed in $70 \%$ ethanol at $60^{\circ} \mathrm{C}$; and stored in same solution. For light microscopy, fresh and fixed worms were cleared in lactophenol. For SEM, specimens were fixed in 3\% buffered glutaraldehyde, washed in cacodylate buffer, and dehydrated in ethanol. After passing through an ascending series of Genesolv D, they were processed in a critical point drier Bomer-900 with Freon 13 , sputter-coated with gold-palladium in a Techniques Hummer V, and examined with an Etec Autoscan at a $20-\mathrm{kV}$ JEOL SEM. Measurements are in millimeter; minim-um and maximum values were given, follo-wed in parentheses by arithmetic mean $( \pm \mathrm{SD})$.

\section{Results}

Echinocephalus overstreeti (L4) Deardorff and Ko (1983), Family: Gnathostomatidae Railliet (1895). Description (10 specimens): Body measured 12.98-22.13 (14.17 \pm 2.03$) x$ $0.387-0.711(0.420 \pm 0.003) \mathrm{mm}$ with very narrow, hardly visible lateral alae some distance posterior to deirids, extended posterior to about anal level. Pseudolabia simple measured $0.037-0.062(0.042 \pm 0.003) \mathrm{mm}$ long with 2 well-developed papillae and amphid. A small rounded interlabia. Cephalic bulb 0.311-0.402 (0.364 \pm 0.002$) \times 0.298-0.404$
$(0.361 \pm 0.002) \mathrm{mm}$ armed with 6 transverse rows of claw-shaped spines measured 0.031$0.062(0.042 \pm 0.002) \mathrm{mm}$ long (including roots). Spines size gradually increased from first to sixth row. Two groups of minute spines, one dorsal and one ventral, between interlabia and first anterior ring of larger spines on cephalic bulb; each group with spines arranged in three rows of $2,2 \& 6 \mathrm{sp}$ ines; 2 larger spine-like formations lateral to third row of 6 spines. Esophagus measured 2.87-3.25 (3.11 \pm 1.01$) \mathrm{mm}$ long. Four cervical sacs present. Nerve ring was 0.521$0.713(0.643 \pm 0.002) \mathrm{mm}$ from anterior extremity. Deirids located just posterior to nerve-ring level. A conical pointed tail measured $0.186-0.387(0.214 \pm 0.002) \mathrm{mm}$ long and equipped with anus.

\section{Taxonomic summary}

Host: common sea bream Pagrus pagrus (Family: Sparidae Rafinesque, 1818)

Infection site: Peritoneal cavity

Locality: Coasts of Hurghada City along the Red Sea, Egypt.

Prevalence: $22 / 35$ fish specimens with $75 \%$ were naturally infected.

\section{Discussion}

In the present study, all fish were clinically normal. This agreed with Rosenthal (1967) who found that heavy infected larvae were harmless to fish host. Springel and Leuchtenberg (1991) reported that effects of larval nematodes on hosts varied depending mainly on larval capsulation encapsulated or noncapsulated. Encapsulated ones caused pathological changes; but non-capsulated ones did not cause pathogenesis (Paperna, 1986).

In the present study, infection increased during winter $(16 / 20,80 \%)$ and decreased during summer $(7 / 15,46.7 \%)$. Vincent and Font (2003) found that prevalence, abundance and intensity were higher in winter than in summer. Ibiwoye et al. (2004) reported that fish susceptibility to infections was due to weakened body post-hibernation. Bhuiyan et al. (2007) found that decrease in water volume in dry season minimized food and 
decreased water temperature made the hosts susceptible to infections by decreasing immune systems. Echinocephalus larvae were attached to host different visceral including genital duct. This agreed with Deardorff and Ko (1983). Adults were recovered from Pastinachus sephen, Myliobatis australis, Urogymnus asperrimus, Taeniura meyeni and $\mathrm{He}$ terodontus portusjacksoni from the Red Sea, Al-Zubaidy et al. (2011) found this parasite for the first time from Abalistes stellatus. In the present study, larvae were isolated from P. pagrus intestine. Also, it was found in $\mathrm{Sa}$ urida undosquamis (Morsy et al, 2015). The present morphology agreed with the descriptions of E. overstreeti of Deardorff and Ko (1983) in presence of very narrow lateral alae, simple pseudolabia, two well-developed papillae and amphid, small rounded interlabia, cephalic bulb and arranged spines. SEM showed that the spines were identical to other reported ones. Spines may differ in different larvae of Echinocephalus species and gave rather reliable taxonomic criteria. But, by SEM can show some of spines missed by light microscope. E. overstreeti differs from all species of the genus by having three preanal, one adanal, and three postarial pairs of papillae. It is similar to $E$. sinensis Ko (1975) in having rugose areas near male cloaca. In $E$. overstreeti, these areas were laterally to cloaca. Also, differ from $E$. sine- $n$ sis in cephalic spines, 31-43 rather than 26-29; in number of adanal pairs and post-anal papillae, one compared with zero, and three rather than four, respectively; and male lacking ventral crests posterior.

\section{Conclusion}

Echinocephalus overstreeti, a nematode parasite recorded from the Red Sea, Egypt as new host record from Pagrus pagrus.

\section{References}

Al-Zubaidy, AB, 2011: Larvae of Echinocephalus overstreeti Deardorff and Ko, 1983 (Nematoda: Gnathostomatidae) in the Red Sea fish, $A b$ alistes stellaris (Balistidae), Yemen coastal water. J. King Abdulaziz Univ. Mari. Sci. 22:31-43. Al-Zubaidy, AB, Mhaisen, FT, Abker, MAM,
2012: Occurrence of five nematode species from some Red Sea fishes, Yemen. Mesopot. J. Mar. Sci. 27, 2:140-56.

Bhuiyan, AS, Akter, S, Musa, GM, 2007: Occurrence of parasites in Labeo rohita (Hamilton) from Rajshahi University. J. Zool. Rajshahi Univ. 26:31-4.

Deardorff, TL, Ko, RC, 1983: Echinocephalus overstreeti sp. n. (Nematoda: Gnathostomatidae) in the stingray, Taeniura melanopilos Bleeker, from the Marquesas Islands, with comments on E. sinensis Ko, 1975. Proc. Helminthol. Soc. Wash. 50:285-93.

De Vantier, LM, Turak, E, Al-Shaikh, KA, Cheung CPS, Abdul-Aziz, M, et al, 2000: Ecological indicators of status of coralcommunities for marine protected areas planning: case studies from Arabia. In: Lloyd D, Done TJ, Diop S (eds) Information management and decision support for marine biodiversity protection and human welfare: coral reefs. UNEP, Nairobi.

González-Solís, D, Soler-Jiménez, LC, Aguirre-Macedo, ML, McLaughlin, JP, Güven, A, et al, 2019: Metazoan parasites of common sole (Solea Solea) and Scaldfish (Arnoglossus laterna) (Pleuronectiformes) from Sinop Coast of Black Sea. Helminthol. 56, 2:132-40.

Ibiwoye, TII, Balogun, AM, Ogunsusi, RA, Agbontale, JJ, 2004: Determination of the infection densities of mudfish Eustrongyloides in Clarias gariepinus and C. anguillaris from Bida flood plain of Nigeria. J. Appl. Sci. Environ. Manage 8:39-45.

Khalifa, RM, Hassan, HA, Mohamadain, HS, Karar, YFM, 2015: Redescription of Pseudolepidapedon Balistis Manter, 1940 and a biological variant (Trematoda: Acanthocolpidae) from the Red Sea fishes; Balistoides viridescens and Rhinecanthus assasi. J. Egypt. Soc. Parasitol. 45, 1:75-84.

Khalil, RH, Saad, TT, Abd El-Hamid, TM, 2014: Some studies on parasitic infestations in some marine water fish with special reference on Isopoda. J. Arab. Aqua. Soc. 9, 1:75-88.

Ko, RC, 1975: Echinocephalus sinensis n. sp. (Nematoda: Gnathostomatidae) from the ray (Aetobatus flagellum) in Hong Kong, Southern China. Oan. J. Zool. 53, 4:490-500.

Moravec, F, Nagasawa, K, 2000: Some anisakid nematodes from marine fishes of Japan \& the North Pacific Ocean. J. Nat. Hist. 34:1555-74. Morsy, K, Bashtar, AR, Abdel-Ghaffar, F, 
Mostafa, N, 2013: New host and locality records of two nematode parasites Dujardinnascaris mujibii (Heterocheilidae) and Hysterothylacium aduncum (Anisakidae) from the common seabream Pagrus pagrus, a light and scanning electron microscopic study. Parasitol. Res. 112, 2: 807-15.

Morsy, K, Bashtar, AR, Mostafa, N, El Deeb, S, Thabet, S, 2015: New host records of three juvenile nematodes in Egypt: Anisakis sp. (Type II), Hysterothylacium patagonense (Anisakidae), and Echinocephalus overstreeti (Gnathostomatidae) from the greater lizard fish Saurida undosquamis of the Red Sea. Parasitol. Res. 114, 3: 1119-28.

Morsy, K, El Fayoumi, H, Al Shahawy, G, Fahmy, M, 2014: Diplectanum harid sp. nov. \& Pseudorhabdosynochus chlorostigma sp. nov. (Monogenea: Diplectanidae) from Scaridae, and Serranidae hosts of the Red Sea. World J. Fish Mar. Sci. 6, 4:319-27.
Olsen, LS, 1952: Some nematodes parasitic in marine fishes. Inst. Mar. Sci. Univ. Texas 11, 2: 173-215.

Paperna, I, 1986: Solving parasite-related problems in cultured freshwater fish. In: Parasitology -Quo-vadit? By Howell, MJ, Proc. $6^{\text {th }}$ Int. Cong. Parasitol. Australian Academy of Science, Canberra.

Rosenthal, H, 1967: Parasites in larvae of herring fed with wild plankton. On a new species Contracaecum (Contracaecum rufai), (family: Heterochelidae Railliet et Henry) from the gizzard of a bird Anhinga rufa Daudin, from lucknow. Mar. Biol. 1:10-5.

Vincent, AG, Font, WF, 2003: Seasonal and yearly population dynamics of two exotic helminths, Camallanus cotti (Nematoda) and Bothriocephalus acheilognathi (Cestoda), parasitizing exotic fishes in Waianu stream, O'Ahu, Hawaii. J. Parasitol. 89:756-60.

\section{Figures explanation}

Figs. A - G: Photomicrographs of Echinocephalus overstreeti ( $4^{\text {th }}$ stage larvae) infecting common sea bream fish, Pagrus pagrus showing: A: whole mount preparation of worm with cephalic bulb (CB). B-G: High magnification of: B: anterior part of larvae terminated anteriorly at cephalic bulb (CB) with bulbous lip (BL), cephalic bulb equipped by 6 rows of spines (S), transverse striations of cuticle (TS). C: cephalic bulb (CB). D, E: spines (S). F: transverse striations of cuticle (TS). G: posterior part of larvae, anus (A), short mucron (M). Figs. H-J:SEM of E. overstreeti showing: H, I: cephalic bulb (CB) with spines (S) and bulbous lip (BL). J: spines (S).
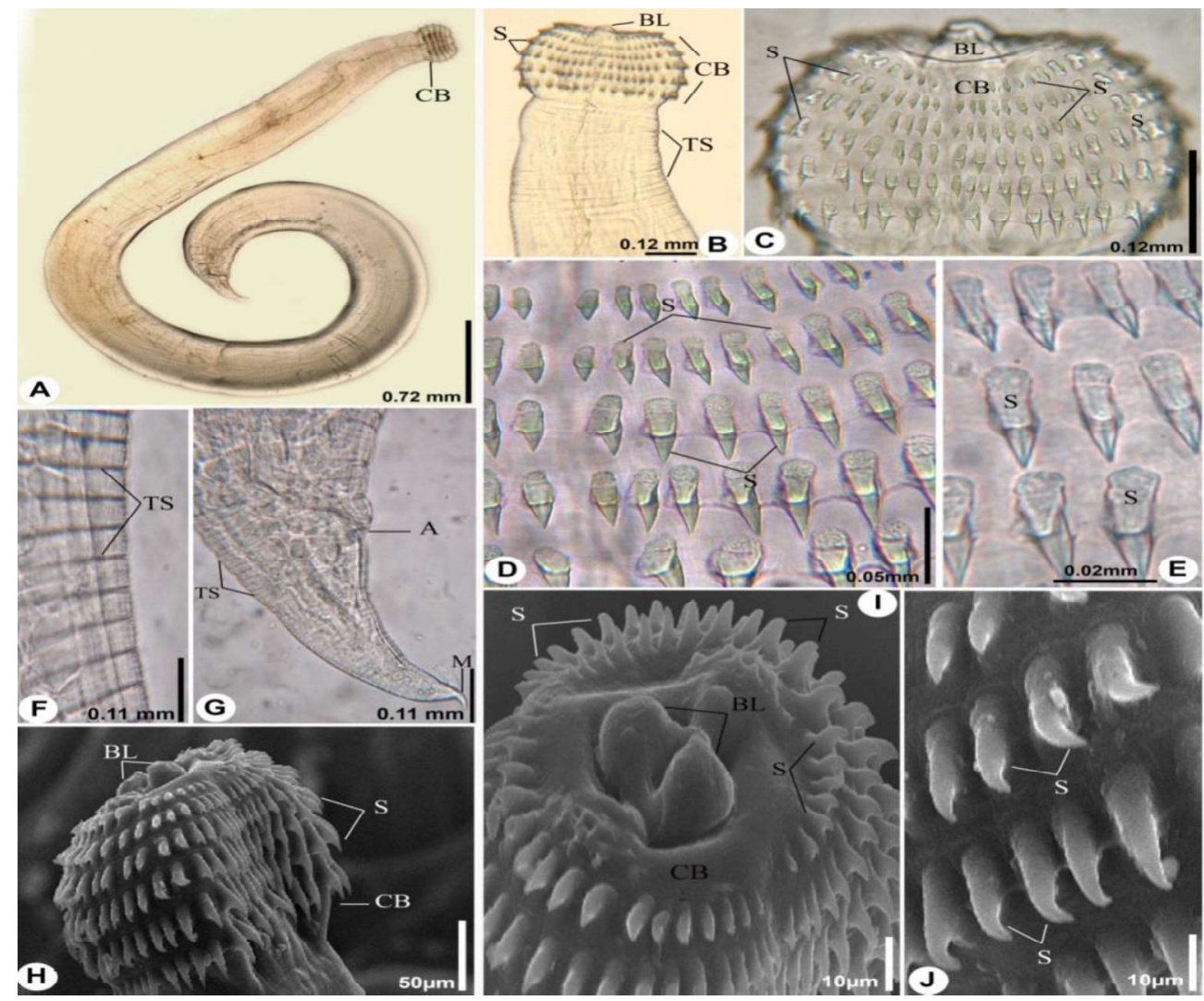